\title{
The Potential of the Dutch Corporate Governance Model for Sustainable Governance and Long Term Stakeholder Value
}

\author{
Manuel Lokin \& Jeroen Veldman*
}

\begin{abstract}
This article addresses the question of how the Dutch regulatory and institutional setting enables policy coherence, specifically with regard to safeguarding stakeholders' interests and promoting sustainable governance. To address this question, we engage with idiosyncratic theoretical notions in the Dutch corporate governance model. We follow the evolution of these notions in statutory company law and case law, their development in the Dutch Corporate Governance Code and their relation to the Enterprise Chamber as a unique institution. We establish how these theoretical views and practical institutions present significant means by which stakeholder concerns may be represented in the operation of company law and corporate governance more broadly and provide a number of ways in which these institutions and their operation can be further developed.
\end{abstract}

Keywords: corporate governance, company law, stakeholders, Dutch Corporate Governance Code, long-termism

\section{Introduction}

In recent years, business leaders, academics, politicians and regulators ${ }^{1}$ have been increasingly concerned with costs and risks linked to the current approach to corporate governance. From the 1970s onwards, a new 'theory of the firm' emerged from the Chicago Schools

Manuel Lokin is Professor of Company Law at Utrecht University and lawyer at Stibbe, Amsterdam. Jeroen Veldman is Visiting Professor at the Interdisciplinary Institute for Innovation at Mines ParisTech in Paris, France and Honorary Senior Visiting Fellow at Cass Business School in London, UK.

1. E.g. Business Roundtable, 2020, 'Statement on the Purpose of a Corporation', https://opportunity.businessroundtable.org/ourcommitment/ (last visited 12-1-2021); L. Fink, 2020, 'A Fundamental Reshaping of Finance', www.blackrock.com/corporate/investor-relations/larry-finkceo-letter (last visited 12-1-2021); The World Economic Forum, 2020 'The Universal Purpose of a Company in the Fourth Industrial Revolution', www.weforum.org/agenda/2019/12/davos-manifesto-2020-theuniversal-purpose-of-a-company-in-the-fourth-industrial-revolution/ (last visited 12-1-2021); and the UK Institute of Directors, 2020, 'IoD Manifesto Corporate Governance', www.iod.com/Portals/O/PDFs/ Campaigns \%20and\%20Reports/Corporate \%20Governance/loD \%20Manifesto \%20-\%20Corporate\%20Governance.pdf? ver=2019-11-19-082215-783 (last visited 12-1-2021). of Law and Economics. Conceiving of the separate legal entity as a convenient but negligible fiction and of the corporation as a nexus of contracts, this new theory reimagined the modern corporation as nothing but a functional outcome of contractual arrangements, in which corporate architecture was understood as an exclusive dyadic arrangement between 'principals' (shareholders) and 'agents' (non-executive and executive directors). ${ }^{2}$ The adoption of these core assumptions of status and architecture, coupled with the increasing use of incentive structures that included share-related variable pay, increasingly oriented and aligned the focus of corporate managers on the production of shareholder value. $^{3}$

As the redevelopment of core assumptions of corporate governance realigned managerial attention and the managerial mandate with shareholder value maximisation, ${ }^{4}$ it allowed for the discounting of long-term considerations connected to corporate strategy and the risks of a short-term focus for broader actors, interests and time frames. ${ }^{5}$ These include risks and costs to corporations, such as operational and reputational consequences, activist responses by Environmental, Social and Governance- (ESG-)oriented shareholders, litigation, insurance costs, regulatory responses, viability of business models and, ultimately, the potential loss of social licence. They also include stakeholder costs and risks associated with contractual protections and human rights in global value

2. M.C. Jensen and W.H. Meckling, 'Theory of the Firm: Managerial Behavior, Agency Costs and Ownership Structure', 3(4) Journal of Financial Economics 305-360 (1976); See also M. Aglietta and A. Rebérioux, Corporate Governance Adrift: A Critique of Shareholder Value (2005); O. Weinstein, 'Firm, Property and Governance: From Berle and Means to the Agency Theory, and Beyond', 2 Accounting, Economics, and Law 1-55 (2012).

3. E.C.H.J. Lokin, De bezoldiging van bestuurders van beursgenoteerde vennootschappen (Executive compensation in listed companies), Instituut voor Ondernemingsrecht (Institute for Company Law, 2018), chapter 7 (in Dutch).

4. A. Jansson, U.L. Olaison, J. Veldman \& A. Beverungen, 'Editorial: The Political Economy of Corporate Governance', 16(1) Ephemera 1-17 (2016); H. Hansmann and R. Kraakman, 'The End of History for Corporate Law,' 89 Georgetown Law Journal 439-468 (2001).

5. R. Davies, A.G. Haldane, M. Nielsen \& S. Pezzini, 'Measuring the Costs of Short-Termism', 12 Journal of Financial Stability 16-25 (2014); K.J.M. Cremers and S.M. Sepe, 'The Shareholder Value of Empowered Boards', 68 Stanford Law Review 67 (2016). 
chains. Finally, they include systemic risks, such as instability in risk allocation in financial markets (e.g. the global financial crisis), political instability (e.g. income inequality and populism) and overshooting planetary boundaries $^{6}$ (e.g. resource depletion, pollution and climate change). Considering the concrete impact of these costs and risks on corporations and the societies they function in, it is relevant to consider how the core assumptions of the current model and its insertion in broad sets of institutions such as accounting norms, directors' duties, shareholder rights directives, corporate governance codes and takeover regulations ${ }^{7}$ may be rethought and redeveloped. ${ }^{8}$

One particularly interesting example of a jurisdiction in which such rethinking is taking place is the Netherlands, where in recent decades an explicit consideration of stakeholder interests and long-term value creation has become a cornerstone of the way in which broad sets of institutions have been developed. In this article, we consider how the idea of the corporation as an 'institution' is used to establish a positive notion of directors' duties in relation to the consideration of stakeholder interests and long-term value creation and how this idea has been implemented throughout statutory law, the Dutch Corporate Governance Code and case law and, more specifically, case law of the Enterprise Chamber of the Amsterdam Court of Appeal and the Dutch Supreme Court.

In the discussion, we examine the potential of this mod$\mathrm{el}$, arguing that the specific conception of the corporation and the comprehensive adoption of this conception provide concrete means by which a broad interpretation of directors' duties may be mandated and defended. From this perspective we argue that the specific stakeholder model developed in Dutch company law and attendant institutions is interesting for the further development of long-term value creation in corporate governance. Conversely, we note how the core of the notion of the corporation as an 'institution' is formulated as an 'open norm' and thus leaves space for directors to pay lip service to this open norm or even to virtually ignore it. As we note how the concrete adoption of such an open norm may be affected by the broader international development of corporate governance institutions that continue to embed and support a, potentially short-term, shareholder value orientation, we argue that the Dutch model offers interesting conceptual and institutional ideas but that its capacity for the protection of stakeholder and long-term interests needs further consideration and development. We will also discuss possible ways of developing the institutional model.

6. K. Raworth, Doughnut Economics: Seven Ways to Think Like a 21stCentury Economist (2017).

7. J. Veldman and H. Willmott, 'The Cultural Grammar of Governance: The UK Code of Corporate Governance, Reflexivity, and the Limits of "Soft" Regulation', 69(3) Human Relations 581-603 (2016).

8. J. Veldman, P. Morrow \& F. Gregor, Corporate Governance for a Changing World: Final Report of a Global Roundtable Series (2016).

\section{Stakeholder Concerns, Sustainable Governance and Long-Termism in the Dutch Institutional Setting}

In this section we will describe some idiosyncratic aspects of the Dutch regulatory setting. We will briefly describe the Dutch notion of the corporation as an institution and the development of this notion in the context of statutory law, the 2016 edition of the Dutch Corporate Governance Code, and in the context of case law of the Enterprise Chamber of the Amsterdam Court of Appeal and the Supreme Court of the Netherlands. ${ }^{9}$ To distinguish between the legal entity and the affiliated business, we use the word 'corporation' when we talk about the legal entity and the word 'undertaking' when we talk about the affiliated business. ${ }^{10} \mathrm{We}$ will use the word 'company' when we talk about the legal entity and the affiliated business together. Furthermore, when we talk about non-executive and executive directors of a one-tier board and supervisory board members and management board members of a two tier board, we will use the word 'director', 'board of directors' or 'board', unless there is a need to make a distinction, in which case we will use the specific terms. ${ }^{11}$

\subsection{A Dutch Company Law Perspective on the Corporation}

The interpretation of the status of the corporation in Dutch company law changed in the years following World War II, when the traditional Dutch view of the

9. In this article, we will not discuss other important Dutch institutions that facilitate the focus on stakeholder interests, such as the Dutch co-determination structure. Although the works council does not formally constitute a body of the company and does not have the right to start inquiry proceedings before the EC, specific rights of employees do find application in corporate governance theory and practice through their application in the co-determination structure. Through the Works Council Act (Wet op de ondernemingsraden) and in specific circumstances through the Dutch Civil Code (DCC), the works councils have been given, inter alia, rights to receive qualified information, nomination and consultation rights in relation to decisions that affect their constituency, such as pensions, working hours, remuneration systems and employment conditions. Notably, information rights mandate the timely and comprehensive disclosure of information in the context of changes in economic context or the ownership structure.

10. "The juridical term "undertaking" captures the sense in which the firm is an organisational unity that combines human and physical assets within a process of production.' S. Deakin, 'Juridical Ontology and the Theory of the Firm', in F. Gagliardi and D. Gindis (eds.), Institutions and Evolution of Capitalism (2019), at 7. https://doi.org/ $10.4337 / 9781785365003.00018$. The term 'enterprise' is often used to denote the same aspects of the corporate structure (e.g. A.A., Berle Jr. 'The Theory of Enterprise Entity', 47(3) Columbia Law Review 343 358 (1947) at 344), but the term 'undertaking' is more distinctive in relation to broader uses of the term enterprise elsewhere, e.g. J.P. Robé, 'The Legal Structure of the Firm', 1(1) Accounting, Economics, and Law 1-86 (2011).

11. In the context of the Dutch legal system, the historically leading board model is that of a two-tier system, in which there is a distinction between the management board and the supervisory board. As of 2013, a one-tier board system may also be adopted. 
corporation as an agreement between shareholders was gradually replaced by what became known as an institutional approach. ${ }^{12}$ This shift towards a new legal doctrine started when the Dutch Supreme Court stated, in 1949 , that directors, while exercising rights conferred on them as members of a body of the company, shall be guided by the interests of the corporation, even if, in their opinion, the interest of the corporation conflicts with the interests of any shareholder. ${ }^{13}$ The notion of the general meeting of shareholders as the supreme power in the company was implicitly dismissed by the Dutch Supreme Court in 1955, when it stated that the general meeting may not exceed the limits of its powers under law and the articles of association. The Supreme Court stressed the division of powers between the board of directors and the general meeting of shareholders, which in this particular case resulted in a ruling that the general meeting could not instruct the directors to repurchase shares because the power to repurchase shares belonged exclusively to the board of directors. ${ }^{14}$

The notion that directors, in the fulfilment of their duties, need to act in the interest of the corporation and its affiliated undertaking, which is not necessarily equal to the (financial) interests of the shareholders, appeared at the centre of the legal debate in the 1960s when two influential Dutch law professors, Prof. Maeijer and Prof. Van der Grinten, provided theoretical bases for the concept of the interest of the corporation and its affiliated undertaking as distinct from the interest of the shareholders. ${ }^{15}$ Acceptance of this concept in Dutch company law literature and case law ${ }^{16}$ in the following decades eventually led to its codification in the Dutch

12. See, inter alia, J.M. de Jongh, 'Een maatschappelijke resultante: Het vennootschapsbelang op de golven van maatschappelijke verandering', in B. Kemp e.a. (ed.), De betekenis en functie van het vennootschappelijk belang, Institute for Company Law, no. 115, 2019, chapter 2; L. Timmerman, 'Het Nederlandse vennootschapsrecht tussen 1918 en 2018, enkele schetsmatige opmerkingen', in H.J. de Kluiver (ed.), Preadvies van de Vereeniging Handelsrecht: 100 jaar Handelsrecht: Over Heden, Toekomst en Verleden, 2018; J.M. de Jongh, 'Tussen societas en universitas, de beursvennootschap en haar aandeelhouders in historisch perspectief' (thesis Erasmus University Rotterdam, Institute for Company Law, 2014), at 322-66.

13. Dutch Supreme Court 1 April 1949, NJ 1949/465, ECLI:NL:HR: 1949:126 (Doetinchemse IJzergieterij): 'dat evenwel commissarissen, rechten uitoefenende, die hun als orgaan der vennootschap zijn toegekend, zich hebben te richten naar het belang der vennootschap en dit moeten doen overwegen, indien dit naar hun oordeel in botsing komt met belangen van welken aandeelhouder ook'. See also Dutch Supreme Court 8 April 1938, NJ 1938, 1076, in which the Dutch Supreme Court set out the principle that shareholders must comply with the articles of association that they themselves have adopted.

14. Dutch Supreme Court 21 January 1955, NJ 1959/43 (Forumbank): 'dat ook de algemene vergadering de bij wet en statuten getrokken grenzen harer bevoegdheid niet mag overschrijden en dat het Hof, in cassatie onbestreden, heeft vastgesteld dat de inkoop van eigen aandelen [in casu] uitsluitend tot de bevoegdheid van de directie behoor'

15. J.M.M. Maeijer, 'Het belangenconflict in de naamloze vennootschap (oratie Nijmegen), 1964', in C.D.J. Bulten, C.J.H. Jansen \& G. van Solinge (eds.), Verspreide geschriften van J.M.M. Maeijer (2009); E.J.J. van der Heijden/W.C.L. van der Grinten, Handboek voor de naamloze en de besloten vennootschap, Zwolle: W.E.J. Tjeenk Willink (1962, 1968, 1976 and 1992).

16. Dutch Supreme Court 13 July 2007, NJ 2007, 434 (ABN AMRO) en Dutch Supreme Court 9 July 2010, NJ 2010, 544 (ASMI).
Civil Code. As per 1976, statutory law explicitly states that supervisory board members, in discharging their duties, shall be guided by the interest of the corporation and its affiliated undertaking, and as per 2013, statutory law explicitly states the same for management board members. ${ }^{17}$

The rather abstract concept of the interest of the corporation has been further clarified by the Dutch Supreme Court in 2014 in its landmark Cancun decision, in which the Supreme Court stated that the interest of the corporation depends on the specific circumstances of the case, but that if an undertaking is linked to the corporation the interest of the corporation generally focuses on promoting the enduring success of the undertaking. Hence, the directors, in the fulfilment of their duties, need to focus on promoting the enduring success of the undertaking. In doing so, the directors must exercise due care towards all those involved, which means that they must avoid unnecessarily or disproportionately damaging the interests of those involved. ${ }^{18}$ Within the Dutch corporate governance model, directors therefore have a positive duty of care towards the company (promoting its enduring success by making business decisions in good faith and in a reasonably prudent manner) and a negative duty of care towards its stakeholders (not unnecessarily and disproportionately damaging their interests). In order to enable the board to promote the enduring success of the undertaking, taking into account the interests of those involved, it will be necessary to grant the board a certain degree of freedom of policy and judgment. ${ }^{19}$ This freedom of policy and judgment translates into a large degree of board autonomy. ${ }^{20}$

17. See Stb. 1976, 395 and Section 2.140 DCC (regarding the naamloze vennootschap) and Section 2.250(2) DCC (regarding the besloten vennootschap). For management board members, see Section 2.129(5) DCC (regarding the naamloze vennootschap) and Section 2.239(5) DCC (regarding the besloten vennootschap).

18. Dutch Supreme Court 4 April 2014, ECLI:NL:HR:2014:797, NJ 2014/286, m.nt. PvS; Dutch Supreme Court 4 April 2014, ECLI:NL:HR:2014:799, JOR 2014/290 m.nt. R.G.J. de Haan; ECLI:NL:HR:2014:804 and ECLI:NL:HR:2014:808 (Inversiones C.s./ Cancun Holding I c.s.).

19. Assink defines freedom of policy as the freedom of choice when setting out the long lines, i.e. in the longer term (which may also have consequences in the shorter term) and freedom of judgment as the freedom of choice when it comes to the course of action in a specific case, i.e. over the shorter term (possibly with a long-term side effect or side effect, although this may not have to be the case). B.F. Assink, Family Companies and Company Interest, Institute for Corporate Law, no. 107 (2017).

20. See about management autonomy Dutch Supreme Court 13 July 2007, NJ 2007/434 (ABN Amro), r.o. 4.3 and Dutch Supreme Court 9 July 2010, NJ 2010/544 (ASMI), r.o. 4.4.1 and recently quoted by the Amsterdam Court of Appeal (Enterprise Chamber) 29 May 2017. ECLI:NL:GHAMS:2017:1965 (Elliott/AkzoNobel), r.o. 3.9 - 3.11. See also, among others, B.F. Assink, Familievennootschap en vennootschappelijk belang (Family company and company interest), Instituut voor Ondernemingsrecht, no. 107 (2017); B.F. Assink, Van vennootschappelijk belang (II, slot), WPNR 2016/7112, June 2016: 'Management autonomy is not a value in itself, but enables directors to protect and promote the company's interest - the content of which depends on the circumstances of the case (and, by extension, to exercise due care in relation to known, legitimate interests of all parties involved in the company and its business)' (translated from Dutch). 
The rise of the institutional doctrine led to the notion that a shareholder is not regarded as the 'owner' of the company. ${ }^{21}$ The undertaking belongs, with all its parts, to the legal entity, and that legal entity is seen as an independent institution. As a result of his contribution, the shareholder receives a share, that is a property right of its own nature, determined by the amount of the share, to which financial rights (a right to receive dividends and a right to share in the liquidation balance) and rights in the area of control (e.g. voting and meeting rights) are attached. ${ }^{22}$ The powers of the board of directors are undelegated: directors do not derive their authorities from the joint shareholders but from the corporate order itself. In principle, therefore, the corporation itself is regarded in company law as a subjurisdiction, governed by law, articles of association, regulations, decisions and the requirement of acting according to the standards of reasonableness and fairness. ${ }^{23}$ The assumption that there is a principal-agent relationship is therefore not reflected in Dutch company law. ${ }^{24}$ The same applies to the approach of the corporation as a nexus of contracts.

\section{Dutch Corporate Governance Code (2016 Edition)}

The institutional doctrine developed in Dutch company law is reflected in the Dutch Corporate Governance Code. ${ }^{25}$ The 2016 edition of the Dutch Code emphasises the notion of the corporation as a long-term alliance between its shareholders and other parties involved. ${ }^{26}$ In contrast to the preamble of the first (2003) and second (2008) edition, which stated that 'The corporation endeavours to create long-term shareholder value', prin-

21. As Edward Rock points out, as a response to the critique of Lynn Stout on shareholder primacy: "Whether the bundle of rights that shareholders have in the corporation can be concisely termed "ownership" is a separate questions [sic] from whether the best description of the corporate form is that it is managed for their benefit.' As already mentioned, the corporation is also not necessarily managed for the benefit of its shareholders in the Netherlands, although their interests may not be disproportionally harmed. Edward Rock, For Whom Is the Corporation Managed in 2020?: The Debate Over Corporate Purpose, Working Paper No. 515/2020, ECGI, September 2020. See also L. Stout, AprilMay 2013, 'The Shareholder Value Myth, European Financial Review', https://ssrn.com/abstract=2277141.

22. J.M.M. Maeijer, 'Het eigendomsrecht op het belang van de onderneming: Walter van Gerven als alternatieve rechter', in H. Couzy e.a. (eds.), Liber Amicorum Walter van Gerven (2000).

23. W.C.L. van der Grinten, "“Structure of the public limited company", Intreerede Katholieke Economische Hogeschool, Tilburg 1951', in C.J.H Jansen C.s. (ed.), Scattered Scriptures by W.C.L. van der Grinten (2004), at 324

24. E.C.H.J. Lokin, 'Het vennootschapsbelang en beloningen (The Interest of the Corporation and Executive Compensation)', in B. Kemp e.a. (ed.), De betekenis en functies van het vennootschappelijk belang, no. 115 (2019), chapter 11.

25. The Dutch Corporate Governance Code applies only to listed companies but has a knock-on effect on non-listed companies.

26. Principle 1.1 DCGC 2016. See also DCGC 2008. ciple 1.1 of the 2016 Dutch Corporate Governance Code ('DCGC 2016') states that: 'The management board focuses on long-term value creation for the corporation and its affiliated undertaking, and takes into account the stakeholder interests that are relevant in this context'. The board should develop a view on long-term value creation by the corporation and its affiliated undertaking and should formulate a strategy in line with this view. ${ }^{27}$ When developing the strategy, attention should in any event be paid to the interests of the stakeholders, defined as groups and individuals who, directly or indirectly, influence - or are influenced by - the attainment of the company's objectives such as employees, shareholders and other lenders, suppliers, customers, the public sector and civil society. Attention should also be paid to any other aspects relevant to the corporation and its affiliated undertaking, such as the environment, social and employee-related matters, the chain within which the undertaking operates, respect for human rights and fighting corruption and bribery. ${ }^{28}$

Although the Dutch Corporate Governance Code is the result of private self-regulation and its provisions are subject to a 'comply or explain' regime, the Supreme Court of the Netherlands noted in the ABN Amro case of $2007^{29}$ how this code and the direction chosen therein could be considered a valid background for the interpretation of societal expectations and norms, colouring, for example, the standards of what is deemed reasonable and fair. And although the DCGC 2016 itself does not construct a direct link between its focus on long-term value creation and the duty of directors to promote the enduring success of the undertaking, the Enterprise Chamber of the Amsterdam Court of Appeal did make this link explicit in the Elliott/AkzoNobel case concerning the refusal of AkzoNobel to engage with PPG to discuss PPG's unsolicited bid. ${ }^{30}$

Hence, the focus on a plurality of interests and longterm value creation is embedded in the Dutch Corporate Governance Code and has been acknowledged in Dutch case law, which mandates the board of listed companies to move away from focusing on any partial interest - such as the interest of the (joint) shareholders - while nevertheless making sure that separate interests are not unnecessarily or disproportionally harmed.

In the DCGC 2016 it is recognised that, depending on market dynamics, it may be necessary to make short-term adjustments to the strategy

28. Provision 1.1.1. DCGC 2016

29. Dutch Supreme Court 13 July 2007, NJ 2007, 434 (ABN AMRO): 'De in Nederland heersende algemene rechtsovertuiging komt onder meer tot uitdrukking in de Corporate Governance Code. De bepalingen uit de CGC geven mede inhoud aan de eisen van redelijkheid en billijkheid naar welke volgens art. 2:8 BW degenen die krachtens de wet of de statuten bij de vennootschap betrokken zijn zich jegens elkaar behoren te gedragen, en aan de eisen die voortvloeien uit een behoorlijke taakvervulling waartoe elke bestuurder op grond van art. 2:9 BW gehouden is'.

30. Court of Appeal of Amsterdam (EC) 29-5-2017, ECLI:NL:GHAMS: 2017:1965, JOR 2017, 261 m.nt. Bulten, r.o. 3.34 (Elliott/AkzoNobel). 


\subsection{The Enterprise Chamber of the Amsterdam Court of Appeal}

An institution that is indispensable in the idiosyncratic institutional make-up of the Netherlands is the Enterprise Chamber of the Amsterdam Court of Appeal ('EC').$^{31}$ In line with the view that the duty of the legal person and those involved in the corporation by virtue of the law and the articles of association is to act fairly and reasonably towards one another ${ }^{32}$ the EC provides the concrete means by which a reasonable solution may be effectuated between such stakeholders. In the case of 'well-founded reasons to doubt the correctness of the policy or the course of business', ${ }^{33}$ the EC provides for inquiry proceedings, in which it may order an independent investigation into the policy and course of business of a corporation. ${ }^{34}$ The inquiry proceedings have two phases. In the first phase, a researcher conducts an inquiry. This phase ends with the deposit of an inquiry report. The applicant ${ }^{35}$ may then decide to ask the EC to investigate whether mismanagement can be established. If mismanagement is established at the end of the second phase of the proceedings, the EC may establish final remedies, which are limited and are explicitly mentioned in Section 2.356 DCC:

i. suspension or nullification of one or more resolutions of a corporate body of the company;

ii. suspension or dismissal of one or more managing or supervisory directors;

iii. appointment of one or more temporary managing or supervisory directors;

iv. temporary deviation from one or more provisions of the articles of association of the company;

v. temporary transfer of shares; and

vi. dissolution of the company.

The inquiry proceedings owe much of their appeal to the possibility that, if, in view of the interests of the legal person and those involved in its organisation by virtue of the law and the articles of association, an interim remedy is required in connection with the situation of the legal person or in the interest of the investigation, the EC may, at any stage of the proceedings, make such an interim remedy for a maximum of the duration of the

31. See Section 2.344 DCC and following. For any individual case, the EC forms a panel of three judges and two councillors with business experience such as managers, directors, accountants with knowledge of management and finance.

32. Section 2.8(1) DCC.

33. Section $2.350 \mathrm{DCC}$.

34. Section 2.345 DCC.

35. Formal applicants who may start these inquiry proceedings before the EC include the following: the corporation itself represented by either the board of directors, the managing board, the non-executive directors or the supervisory board (or in bankruptcy by the curator), shareholders and holders of depository receipts (if they meet a certain threshold), members of an association or a cooperative (if they meet a certain threshold), persons who are authorised to do so by the articles of association or under an agreement, an association of employees that has among its members persons working for the undertaking (e.g. labour unions), and the advocaat-generaal at the Public Prosecutor's Office for reasons of public interest. proceedings. ${ }^{36}$ These interim remedies are not limited in form as opposed to the final remedies mentioned before. And although the interim remedies are provisional, they may nevertheless have a far-reaching effect because, for example, the temporary appointment of a director may be provisional, but the decisions made by this director are not. Examples of such interim remedies are suspension of one or more managing or supervisory directors, appointment of one or more temporary managing or supervisory directors, selected by the EC itself, with casting or decisive votes and specific representation rights, temporary deviation from one or more provisions of the articles of association of the company and temporary transfer of shares to a custodian who may cast votes on these shares. The aim of such interim remedies may be to make sure that the status quo is preserved, that both shareholders and management are denied from taking irreversible acts or that parties may be instructed to find an amicable solution, where necessary aided by independent outsiders. ${ }^{37}$ These interim remedies give the EC broad powers to indirectly intervene in the direction of a company. In many cases, obtaining such interim remedies is the sole purpose for starting inquiry proceedings, and obtaining them will end the dispute before the inquiry has even started.

As a dedicated legal institution with broad powers to arbitrate over the affairs of corporations at the request of specific stakeholders or the corporation itself in matters relating to corporate governance, and notably with the power to either directly or indirectly intervene in the existence, constitution, operation and strategy of a corporation, the EC may be considered a unique institution in the world.

\subsection{Recent Case Law of the Enterprise Chamber} and the Dutch Supreme Court

The development of the institutional doctrine, and especially the interpretation of the focus on the interest of the corporation in relation to shareholders' rights, has recently been the focus of a number of proceedings handled by the EC and the Dutch Supreme Court. We will discuss two:

i. Elliott $\mathrm{v}$ AkzoNobel regarding a potential takeover of AkzoNobel by PPG and shareholders' right to convene a general meeting to vote on the dismissal of the chairman; ${ }^{38}$ and

ii. Fugro $\mathrm{v}$ Boskalis regarding shareholders' right to vote on the desirability of dismantling anti-takeover measures.

To provide some background, the DCGC 2016 states that, under takeover conditions, the board should ensure that the stakeholder interests concerned are care-

36. Section 2.349a(2) DCC. See F. 'Eikelenboom, De (onmiddellijke) voorziening van de enquêteprocedure' (thesis University of Groningen, Instituut voor Ondernemingsrecht, 2017), no. 105.

37. J. Van Bekkum e.a., 'Corporate governance in the Netherlands', 14 Electronic Journal of Comparative Law 23 (2010).

38. For reasons of transparency, we want to disclose that one of the authors was involved in the Elliott/AkzoNobel-case as one of the lawyers of the supervisory board of AkzoNobel. 
fully weighed and any conflict of interest for board members is avoided. The board should be guided in their actions by the interests of the corporation and its affiliated undertaking. ${ }^{39}$ As a result, whereas in the UK, the board may not frustrate the bid of a hostile bidder, in the Netherlands there is no explicit requirement for the board not to frustrate an unsolicited offer. Similarly, there is no requirement to choose the highest bid in a takeover situation. Delaware's Revlon Rule therefore does not apply as guiding legal principle in the Netherlands. ${ }^{40}$

The focus on the interest of the company under takeover conditions is further reinforced in recent case law. In the aforementioned Elliott/AkzoNobel case, the EC considered that the Cancun decision, in which the interest of the corporation is considered (in principle) equal to promoting the enduring success of the undertaking, was in line with the objective of long-term value creation as established in the Dutch Corporate Governance Code 2016:

When assessing proposals of a potential bidder, the management board of a target company should also, under the supervision of the supervisory board, focus - in the terms of the Corporate Governance Code - on the long-term value creation of the corporation and its affiliated undertaking and, to this end, weigh the relevant interests of the stakeholders. ${ }^{41}$

\section{Taking this as its point of departure, the EC ruled:}

This guideline logically implies that it is conceivable that the target corporation decides not to support a proposal of a potential bidder, even if a majority of the shareholders of the target corporation would wish to accept a corresponding bid. For the same reason, it is equally conceivable that the target corporation decides not to support a potential bidder's proposal while a stand-alone scenario is likely to generate less shareholder value (in the long term) than the takeover proposal (in the short term). In short, the fact that a decision by the target corporation not to support a bid does not correspond to the will of (a majority of) the shareholders does not necessarily mean that the target corporation could not reasonably have reached that decision [emphasis added]. ${ }^{42}$

The EC ruled that denying the shareholders of AkzoNobel their right to convene an extraordinary general

39. Principle 2.8 DCGC 2016

40. Revlon, Inc. v. MacAndrews \& Forbes Holdings, Inc., 506 A.2d 173, 182 (Del. 1958). 1958). The Revlon Rule is the legal principle stating that, when a corporation is sold for cash, the duty of the board of directors is to secure the highest value reasonably available for shareholders. The board may not balance the interests of shareholders against those of other stakeholders.

41. Court of Appeal of Amsterdam (EC) 29 May 2017, ECLI:NL:GHAMS: 2017:1965, JOR 2017, 261 m.nt. Bulten, r.o. 3.34 (Elliott/AkzoNobel).

42. Court of Appeal of Amsterdam (EC) 29 May 2017, ECLI:NL:GHAMS 2017:1965, JOR 2017, 261 m.nt. Bulten, r.o. 3.34 (Elliott/AkzoNobel). Please note that in the AkzoNobel case the fact that the proposal of PPG was unsolicited played an important role. meeting to decide on the dismissal of the chairman of the supervisory board did not result in well-founded reasons to doubt the correctness of the policy or the course of business at AkzoNobel, because calling such a meeting, in this particular case, constituted an attempt to influence the direction of the strategy, while the power to determine the strategy fell exclusively within the powers of the board. ${ }^{43}$ As already stressed by the Supreme Court in the ASMI case, it is up to the management board, under the supervision of the supervisory board, to assess whether and to what extent it is desirable to enter into consultation with the shareholders about the strategy. ${ }^{44}$ In relation to these circumstances, the shareholders' demands for an inquiry and for an interim remedy containing the convocation of an extraordinary general meeting (EGM) were dismissed. ${ }^{45}$

The fact that the Shareholders Request ${ }^{46}$ states that the EGM request is not intended to influence AkzoNobel's ultimate strategy - given the lack of shareholder control over the strategy and the response time set out in the Corporate Governance Code - is not surprising, but does not reflect reality. The shareholders on whose behalf the Shareholder Request has been made will, as professional shareholders, have realized that, as discussed above, negotiations with PPG will not be without engagement for AkzoNobel. Apart from the internal e-mail exchange within Elliott of April 11, 2017 showing possible alignment with PPG, AkzoNobel could interpret the Shareholder Request as aimed at the acquisition of control by shareholders over AkzoNobel's position in response to PPG's proposals and thus over AkzoNobel's strategy. Given the starting point that it is up to the management board, under the supervision of the supervisory board, to assess whether and to what extent it is desirable to enter into consultation with the shareholders about the strategy (Supreme Court 9 July 2010, ECLI:NL:HR:2010:BM0976 (ASMI)), in the preliminary opinion of the EC the rejection of the Shareholder Request cannot, in the given circum-

43. The EC notes that it does not enter into the question of whether a request to the interim injunction judge for authorisation to convene a shareholders' meeting can be granted. Under Dutch company law, shareholders themselves may take the initiative to convene a general meeting in accordance with Sections 2:110 and 2:111 DCC. The EC considers: 'Elliott and other shareholders went down this road although this attempt was aimed more at bringing about a change in AkzoNobel's course of business than at the management board and supervisory board rendering account of the chosen course of business but they did not comply with this in the form of a request for authorization to the Court in preliminary relief proceedings pursuant to Section 2:110 DCC.' Elliott did such a request, together with York, after its defeat by the EC, but again without any luck. The Court ordered that the request was premature. Elliott had to wait until after AkzoNobel had accounted for its actions, including its decision not to reach out to PPG, in the EGM that AkzoNobel had convened during proceedings. A standstill agreement was signed days after the denial by the Court.

44. Dutch Supreme Court 9 July 2010, ECLI:NL:HR:2010:BM0976 (ASMI).

45. Court of Appeal of Amsterdam (EC) 29 May 2017, ECLI:NL:GHAMS: 2017:1965, JOR 2017, 261 m.nt. Bulten, r.o. 3.28 (Elliott/AkzoNobel).

46. Being the request of Elliott c.s. to convene an extraordinary general meeting to decide on the dismissal of the chairman of the supervisory board of AkzoNobel. 
stances, be regarded as a valid reason to doubt the correct policy and course of affairs. ${ }^{47}$

In the Fugro/Boskalis case, which concerned the dissolution of a protective measure, the Dutch Supreme Court argued along similar lines that if a topic is not covered by the competence of the general meeting of shareholders, it may be offered as an item on the agenda of the general meeting for discussion, but it may not be voted upon, even if it concerns a non-binding vote (regardless of whether it is labelled as an advisory vote or a shareholders' poll or survey), unless the board voluntarily puts the item up for such a vote. ${ }^{48}$

These cases of the Dutch Supreme Court and the EC confirmed the notion of the corporation as an institution in company law, a clear division of powers between the general meeting and the board of directors whose powers are derived from the corporate order itself, and therefore, implicitly, the notion that the general meeting of shareholders is not the supreme power within the corporation. Furthermore, the Supreme Court and the EC linked the corporation as an institution to the notion that the board should be guided by the interests of the corporation and its affiliated undertaking, in the DCGC 2016 described as creating long term value, which means that directors, in fulfilling their duties, should promote the enduring success of the undertaking while making sure that the legitimate interest of its various stakeholders are not unnecessarily and disproportionally harmed, which in turn results in a fairly broad degree of management autonomy.

\section{Current Limitations of the Dutch Company Law System}

Although the interest of the company as a guideline for board members ensures that interests other than those of shareholders may prevail, it does not mean that the board of directors or an individual board member is prohibited from acting primarily in the interests of shareholders, within the policy and discretion left to the board (member). One of the limitations of Dutch company law is that it does not generally concern itself with enforcing the optimal performance of director duties. Company law provides only general guidance as to what conduct or action is required of a director. Moreover, company law provides remedies only in the event that director behaviour reaches the outer limits of what is deemed appropriate. A distinction is therefore made in Dutch literature between the standards of conduct that a board member has to observe and the less stringent assessment standards that the court applies when assess-

47. Court of Appeal of Amsterdam (EC) 29 May 2017, ECLI:NL:GHAMS 2017:1965, JOR 2017, 261 m.nt. Bulten, r.o. 3.28.

48. Dutch Supreme Court 20 April 2018, ECLI:NL:HR:2018:652, NJ 2018, 331 m.nt. PvS. ing the behaviour and actions of board members. ${ }^{49}$ The fact that the standards of conduct and the standards that apply to the assessment of director behaviour differ is not surprising, because it ensures that the board is given the necessary freedom to do business as it sees fit. ${ }^{50}$ In order for a course of conduct to be regarded as unlawful by a Dutch court, it must be sufficiently clear that that freedom has been or is being exercised in such a way that, in objective terms, it does not deserve to be respected by law, for example when the actions of a director are qualified as seriously reproachable towards the corporation or a third party, resulting in directors' liability, or as contrary to elementary principles of entrepreneurship, resulting in the EC establishing mismanagement. ${ }^{51}$

This freedom plays an important role in the assessment of director actions in light of the company's interests. The standard that the company's interest must be taken into account therefore does not function as a fixed guideline for directors but as a requirement for accountability within a framework determined by law and reasonableness. In assessing whether the requirement has been met, the parties concerned will necessarily have to be left a certain margin of discretion. ${ }^{52}$ Board members therefore have a certain amount of policy and discretion to determine which actions promote the enduring success of the undertaking in question. ${ }^{53}$ This freedom translates into an extremely cautious examination of the merits of business decisions, focusing merely on the process that led up to the decision. ${ }^{54}$

49. A distinction is made between standards of conduct, liability standards and assessment standards. See L. Timmerman, 'Toetsing van ondernemingsbeleid door de rechter, mede in rechtsvergelijkend perspectief Over het onderscheid tussen gedragsnormen en toetsingsnormen', Ondernemingsrecht 555 (2003); L. Timmerman, 'Grondslagen van geldend ondernemingsrecht', 2 Ondernemingsrecht 3 - 6 (2009); See also P. Olden, 'Bestuur en aansprakelijkheid: intuïtief door de grijze zone', 83 Ondernemingsrecht 454 - 459 (2019), who criticises the usefulness of making such a distinction.

50. There is no statutory business judgment rule as is established in, for example, the USA and Germany. In Dutch company law director liability exists only when a high liability threshold has been met: acting serious culpable. Dutch Supreme Court 20 June 2008, ECLI:NL:HR: 2008:BC4959, NJ 2009/21, confirmed, inter alia, in Dutch Supreme Court 05 September 2014, NJ 2015/22, 4.2 (RCI).

51. See B.F. Assink, Baanbrekend, WPNR 7230 (2019), at 205, on this cautious assessment. See for example Dutch Supreme Court 10 January 1997 (Staleman/Van der Ven); Dutch Supreme Court 8 December 2006 (Ontvanger/Roelofsen)

52. P. van Schilfgaarde e.a., Van de BV en de NV (2017), at 29-30.

53. Assink describes the obligation of the directors as follows: 'Management board members are not obliged (...) to achieve that enduring success of the undertaking, but to take the necessary steps to promote such success in a loyal and careful manner, on the basis of the insight and care that may be expected - also in view of the company and undertaking in question - of a management board member who is prepared for his task and conscientiously performs this task.' B.F. Assink, Van vennootschappelijk belang (II, slot), WPNR 2016/7112, June 2016.

54. Did the board of directors arrive at the business decisions in a careful, reasonable and informed way? This reticence is not limited to an assessment of the company's interest, but also applies, for example, in the case of an assessment of resolutions of the management board against the reasonableness and fairness of Section $2.8 \mathrm{DCC}$, as expressed by the Supreme Court in VEB/KLM: 'However, this does not detract from the fact that restraint fits in with the assessment of whether a body of a legal person, in taking a decision, has weighed up all the relevant inter- 
Certain circumstances, such as the presence of a conflict of interest on the part of a board member, may affect the aforementioned board discretion and may justify a more intrusive review by the court. ${ }^{55}$ The duty to act in the interest of the corporation and its affiliated undertaking implies a duty of loyalty (Dutch style). In Dutch company law, however, the presence of a conflict of interest, even if the director has a personal interest in the matter, is by no means a given. A restrictive approach has been adopted by the Dutch Supreme Court that is reflected in the material interpretation of the concept of conflict of interests in the Bruil-case. ${ }^{56}$ This material interpretation implies that, taking into account all relevant circumstances of the case, the question of whether there is a conflict of interest is whether the board member is dealing with such incompatible interests that it can reasonably be doubted whether the board member acted solely on the basis of the interest of the corporation and the undertaking connected therewith. ${ }^{57}$ The purpose of the conflict of interest rule is to prevent a board member from being guided in his actions by his personal interest rather than (exclusively) serving the interest of the corporation and its affiliated undertaking. ${ }^{58}$ However, this does not mean that the statutory conflict of interest rule tries to prevent the weighting of the interest of the corporation from being made by a board member who also has an interest of his own in the decision to be taken. ${ }^{59}$ The challenge is to demonstrate that there is a conflict between the interest of the company on the one hand to be determined (eventually by the court) at that moment on the basis of all the circumstances of the case - and the personal interests of the board member on the other. This challenge is all the greater because most business decisions are reviewed on the basis of the principle that, as long as it is not sufficiently clear that there is a conflict of interest, there is a parallelism of interests. ${ }^{60}$ This is why Dutch company law, for

ests in accordance with the principles of reasonableness and fairness, and has taken the necessary care in doing so'. Dutch Supreme Court 12 July 2013, NJ 2013/461 m.nt. PvS (VEB/KLM), 3.4.3.

55. For example, by making higher demands on the care that a director has to take. See B.F. Assink, Baanbrekend, WPNR 7230 (2019), at 205/206 and for example EC 17 February 2009, ARO 2009/45, 3.14.

56. Dutch Supreme Court 29 June 2007, NJ 2007/420 m.nt. Ma, r.o. 3.4. (Bruil), JOR 2007/169, Leijten and Bartman.

57. Dutch Supreme Court 29 June 2007, NJ 2007/420 m.nt. Ma, r.o. 3.4. (Bruil), JOR 2007/169, Leijten and Bartman. 'Does he have an interest, of whatever nature, that conflicts with his duty to serve and prioritize the corporate interest? Or does he perhaps have two duties that conflict with each other?' A.F.J.A. Leijten, 'Bestuur en tegenstrijdig belang', 80 Ondernemingsrecht 432 - 435 (2019), Para. 5.

58. Dutch Supreme Court 9 July 2004, NJ 2004, 519 (Duplicado/Goedkoop).

59. See in detail A-G Timmerman in his conclusion to Dutch Supreme Court 29 June 2007, NJ 2007/420 m.nt. Ma (Bruil). This approach is also in line with the view taking in financial economy, in which having one's own interest is a given and in which a parallelism of interests is therefore sought.

60. As a rule, this principle does not apply in cases where a director enters into an agreement with himself in private. In such events, there is reason to suspect the presence of a conflict of interest unless there are clear indications that the interest of the company and the interest of the management board member run parallel. See A-G Timmerman's conclusion on HR 29 June 2007, NJ 2007/420 m.nt. Ma (Bruil) and the example, does not per se prohibit aligning executive remuneration with the interest of shareholders despite its stakeholder model. ${ }^{61}$ Neither the conflict of interest rule itself nor the guideline that board members should focus on the interests of the corporation and its affiliated undertaking, therefore, does guarantee that individual board members will not act primarily in the interests of only one stakeholder.

\section{Proposed Solutions and Recent Developments}

The notion that the board's duties are directed towards the interest of the corporation and its affiliated undertaking functions as an 'open norm', which means that the concrete implementation of a focus on the long-term interest of the corporation as a whole remains very much dependent on the concrete direction chosen by the board. The criticism of the stakeholder model focuses precisely on this large degree of autonomy granted to the board of directors without providing the board of directors with a clear direction on how to discharge their duties for which the directors can be held accountable. As shown in the previous paragraph, to a certain extent this criticism applies equally to the current Dutch corporate governance model. Although the interest of the company is an interest in its own (i.e. independent of other interests), the vision of the board of directors in interpreting that interest is, although not decisive, of great importance when the interest is being reviewed by a court. Proponents of the shareholder model dismiss the stakeholder approach owing to the lack of a clear direction that this model provides to directors on how to discharge their duties, stating that their model at least gives the board of directors a clear, straight-forward and objectively verifiable direction to fulfil their duties for which directors can actually be held accountable.

Apart from the fact that the interests of shareholders are not as homogeneous as envisaged, and that the interests of shareholders in the long term provide a more obscure direction than suggested, current criticism on the shareholder model focuses merely on the generic, one-sided purpose given to any corporation, while also opting for an unbalanced and uninspiring one: to maximise value for only one stakeholder. The rejection of maximising shareholder value as the sole purpose of the corporation directly undermines the justification for the notion that,

contribution on this judgment of Dortmond in Ondernemingsrecht: P.J. Dortmond, HR 29-06-2007, no. C06/041HR: Bruil Kombex, Ondernemingsrecht 2007, 126, no. 5. Furthermore, as presented in recent case law, the EC takes a different stand towards potential conflicts of interest and demands a higher standard of transparency and diligence in the decision-making process if personal interests or a conflict of duties is involved, see e.g. EC 22 December 2017, ECLI:NL:GHAMS: 2017:5354 (Intergamma), EC 10 December 2019, ECLI:NL:GHAMS: 2019:4359 (Estro), EC 24 January 2020, ECLI:NL:GHAMS:2020:144 (DeSeizoenen).

61. Lokin, above n. 24. 
if stakeholder interests are in conflict with each other, the board of directors should at all time favour the interest of shareholders above all else in making their business decision, as the shareholder model dictates. The debate between the two groups therefore seems to be about the undesirability of either being roughly right or being precisely wrong.

The question that remains unanswered is what solution could meet the criticism on the lack of a clear direction that the stakeholder model provides. The clarification of the Dutch Supreme Court in the Cancun decision, that the interest of the corporation depends on the circumstances of the case, but that, if the corporation is associated with an undertaking, the interest of the corporation is in principle primarily determined by promoting the enduring success of the undertaking, meets the aforementioned criticism to the extent that it provides some direction. In judicial review of the interest of a certain corporation the court is able to look at the specific circumstances of the case, and it is well accepted that the actual characteristics of the corporation and its undertaking (or, in other words, its undefined purpose) and the identification of the stakeholder interests affected by the corporation and its affiliated undertaking limit the discretionary space for the board of directors in interpreting the interest of the company. ${ }^{62} \mathrm{~A}$ disadvantage is, however, that it is up to the court to identify, with a degree of restraint, the specific characteristics and stakeholders that are then used as a basis for a judicial review of the challenged actions.

In our opinion, a solution for the lack of direction for directors to discharge their duties can be found in the worldwide discussion concerning the need to formulate a clear purpose or raison d'être of the company. ${ }^{63}$ This worldwide debate delivers lines of thinking that make it possible to depart from the generic purpose that would apply to any company, namely that the only purpose of business is to increase its profits for its shareholders within the rules of the game. It advocates a tailor-made purpose that does justice to the distinct right to exist of the company in question. The pursuit of profit, which in the shareholder model evolved into the pursuit of shareholder value maximisation, thus acquires a different, serving role; no longer as an end goal but as a condition for existence and for promoting the enduring success as defined. For the Dutch corporate governance model, the solution can be found in formulating a purpose or, more particularly, in specifying the enduring success of the undertaking in question.

62. These limitations are especially apparent in cases where societal interests are evident (e.g. day care and health care providers), see, for example, EC 27 May 2010, ECLI:NL:GHAMS:2010:BM5928 (PCM); EC 10 December 2019, ECLI:NL:GHAMS:2019:4359 (Estro), EC 24 January 2020, ECLI:NL:GHAMS:2020:144 (DeSeizoenen), EC 21 July 2020, ECLI:NL:GHAMS:2020:2033 (Stichting Katholieke Universiteit)

63. See, for instance, recent statements by BlackRock chief executive Larry Fink, the World Economic Forum, Bank of England chief economist Andy Haldane, the US Business Roundtable, US law firm Lipton, Wachtell, Rosen and Katz, the French Loi Pacte and a statement by twentyfive Dutch corporate law professors.
Within the Dutch corporate governance model, the formulation of the company's purpose would not be without obligations. It will have a direct effect on the open standards against which the board of directors is assessed. Formulating the company's purpose determines the enduring success of the undertaking that the board of directors has to promote. Even more than in the shareholder model, this creates a clear direction for the board of directors to focus on in performing their duties and an assessment framework to review directors' actions. Actions in violation of the purpose of the company can be scrutinised in a court of law. A first call for such a purpose to be enshrined in the articles of association has recently been made in the Netherlands by twenty-five Dutch professors of corporate law (including one of the authors of this article). ${ }^{64}$ In our view, the combination of the Dutch institutional model and the formulation of a company-specific purpose will largely address the existing weaknesses of the Dutch corporate governance model. The same applies to a direct specification of the enduring success of the undertaking.

\section{Discussion: The Dutch Institutional Setting From a Theoretical and Comparative Perspective}

We have shown how Dutch company law has adopted an 'institutional' approach in which the corporation is conceived as a subjurisdiction and the powers of directors are undelegated. In this model, shareholders are considered a stakeholder with similar, but not automatically prioritised, claims compared with other stakeholders. With the duty of the board perceived as the promotion of the long-term interests of the corporation and, more specifically, the enduring success of its affiliated undertaking, and the joint shareholder interests interpreted and treated as a qualified, rather than an overriding interest, it makes sense that the management board and the supervisory board are mandated and are considered to have overall responsibility to prioritise the enduring success of the corporation and its affiliated undertaking. Derived from this is the general rule established in case law that determining the strategy of a company is, in principle, a matter for the board of management, for the supervisory board to supervise and for the general meeting of shareholders to be able to express its views on this matter by exercising the rights granted to it by law and the articles of association. In general, this means that the management board of a corporation is accountable to the general meeting of shareholders for its policy, but that, except where otherwise provided by

64. L. Timmerman e.a., 'Naar een zorgplicht voor bestuurders en commissarissen tot verantwoordelijke deelname aan het maatschappelijk verkeer', 86 Ondernemingsrecht 471 - 474 (2020). 
law or the articles of association, it is not obliged to involve the general meeting in advance in its decisionmaking with regard to acts for which the management board is competent. ${ }^{65}$ The result is that in Dutch company law director primacy prevails over shareholder primacy.

Hence, it is a series of conceptual choices following from the interpretation of the corporation as an 'institution' that explicitly mandates, provides discretionary space and protects the board members as they focus on stakeholder interests and the long-term interests of the company as a whole. As these conceptual choices find a comprehensive embedding in institutions like statutory law, the corporate governance code and case law, and as these choices are reinforced in concrete corporate governance issues like takeovers, this results in a comprehensive approach to the role and position of stakeholders and long-term value creation in the area of corporate governance and their comprehensive embedding in the fabric of Dutch company law.

\section{A Theoretical and Comparative Perspective}

The choices underlying the embedding of this institutional model are interesting from both a theoretical and a comparative point of view. It is interesting to note that a clear evolution is visible in the interpretation of these ideas. Remarkably, shareholder value has never been accepted by the Dutch Supreme Court as the leading corporate interest in the period following World War II, despite the broad acceptance of a more enlightened shareholders model in practice in the 1990s and onward, as reflected by the notion in the DCGC 2003 and DCGC 2008 that the management board should focus on creating long-term shareholder value. Instead the Dutch Supreme Court consistently adheres to the idea that directors should focus on the interest of the corporation and its affiliated undertaking. ${ }^{66}$ It is this interest that has been codified in statutory law and was further specified in the Cancun case in 2014 as being the enduring success of the undertaking with the notion that in the discharging of this duty directors must avoid unnecessarily or disproportionately damaging the interests of those involved. The enduring success of the undertaking was further embedded in the DCGC 2016 with the formulation that 'The management board focuses on long-term value creation for the corporation and its affiliated undertaking, and takes into account the stakeholder interests that are relevant in this context'. Hence,

Dutch Supreme Court 13 juli 2007, JOR 2007/178, m.nt. Nieuwe Weme, ECLI:NL:HR:2007:BA7972 (ABN AMRO) and Dutch Supreme Court 9 juli 2010, JOR 2010/228, m.nt. Van Ginneken, ECLI:NL:HR: 2010:BM0976 (ASMI). Please note that this rule does not necessarily have to apply to corporations with only a few shareholders, EC 27 February 2020, ECLI:NL:GHAMS:2020:717 (Fuel Plants).

66. See Section 2.129(5) DCC regarding the naamloze vennootschap and in Section 2.239(5) DCC regarding the besloten vennootschap).
$2008-2016$ saw a distinct shift in the interpretation of the interest of the corporation in the Dutch corporate governance model. Particularly in response to the global financial crisis, the interpretation of the interest of the corporation as an institution is broadened to explicitly include broader stakeholders' interests and other aspects relevant to the corporation and its affiliated undertaking, such as the environment, social and employee-related matters, the chain within which the undertaking operates, respect for human rights, and fighting corruption and bribery. This broadening of the perception of valid interests is reinforced by the explicit inclusion of these interests in the DCGC $2016^{67}$ and the acknowledgment of this perception by the EC and the Dutch Supreme Court. More specifically, this broadening is visible in the explicit relinquishing of (long-term) shareholder value, which was still the leading conception of corporate interest in the DCGC 2008.

In theoretical terms, the Dutch legal model is interesting because it moves away from the view that the corporation is a private contractual construct and towards a view that the corporation can be perceived as an institution that represents an amalgam of interests. Arguably, a theoretical view that interprets the interest of the corporation as the sustainable interest of the corporation and its undertaking, in particular, relates well to the ideas developed by Berle and Means, ${ }^{68}$ Team Production Theory ${ }^{69}$ and the perception of the corporation as a 'commons' ${ }^{70}$ However, it is the comprehensive development and insertion of these abstract theoretical concepts across legal institutions with a soft law and a hard law status, and the unique provision of the $\mathrm{EC}$ with its powers to adjudicate and intervene in matters of corporate control, in particular, that are of particular interest. As these institutions provide practical means by which directors' duties may be focused on the interest of the corporation and the affiliated undertaking and by which the mandate and discretionary space for directors to take on board stakeholder interests and a focus on the long term may be embedded and safeguarded, these theoretical redevelopments and concrete institutions are interesting from a comparative perspective as well. ${ }^{71}$

Another interesting aspect of the Dutch legal model is the way in which the interests of the corporation and its affiliated undertaking come together. ${ }^{72}$ Although it may

67. See best practice provision 1.1.1. DGCG 2016

68. A.A. Berle and G.C. Means, The Modern Corporation and Private Property (2007[1932]); O. Weinstein, 'Firm, Property and Governance: From Berle and Means to the Agency Theory, and Beyond', 2(2) Accounting, Economics, and Law 1-55 (2012)

69. M.M. Blair and L.A. Stout, 'A Team Production Theory of Corporate Law', 85(2) Virginia Law Review 247-328 (1999).

70. S. Deakin, 'Corporation as Commons: Rethinking Property Rights, Governance and Sustainability in the Business Enterprise', 37(2) The Queen's LJ 339-81 (2012).

71. A. Keay, 'Ascertaining the Corporate Objective: An Entity Maximisation and Sustainability Model', 71(5) The Modern Law Review 663-98 (2008). doi:10.1111/j.1468-2230.2008.00711.x

72. See, in this regard, E. Rock, 'For Whom is the Corporation Managed in 2020?: The Debate Over Corporate Purpose', Working Paper No. 515/2020, ECGI, September 2020. 
be beneficial from a theoretical perspective to distinguish between the interest of the corporation and the interest of the undertaking, we should not ignore the fact that these two interests are inextricably linked to each other. Ignoring this fact could lead to a schizophrenic view of directors' duties with regard to managing the undertaking on the one hand and directing the corporation on the other. ${ }^{73}$ The Dutch model acknowledges the interaction of the two interests and designates the interest of the undertaking, which includes having an eye for the interests of those who are employed by and of those who have financed the undertaking, as the overriding interest that shapes the interest of the corporation. In doing so, the model is moving away from an isolated and more theoretical legal discussion about whom the corporation is managed for and towards an emphasis on the enduring success of the specific undertaking directors are running.

\section{Concluding Remarks}

To engage with the way the Dutch regulatory and institutional setting enables policy coherence, and specifically with regard to safeguarding various stakeholders' interests and promoting sustainable governance, we took a closer look at the Dutch corporate governance model as an example of a system in which stakeholder rights and claims are significantly recognised and inserted into relevant institutions. We followed the evolution of idiosyncratic theoretical notions in Dutch statutory company law and case law, their development in the Dutch Corporate Governance Code and their relation to the $\mathrm{EC}$ as a unique institution. We noted the direct relevance of these views and practical institutions for the representation of stakeholders in the operation of company law and corporate governance more broadly. In addition, we have noted how Dutch company law has developed innovative conceptual and practical means by which a long-term stakeholder-oriented corporate governance model may be conceived and implemented and thus presents considerable potential to inform the theoretical and comparative company law debate on these issues.

Despite the perceived merits of the institutional model, however, we note that there is no overriding mechanism that concretely impedes the capacity for directors to put shareholder interests first or to focus on short-term market value increases. In practice, the notion that the board's duties are directed towards the interest of the corporation and its affiliated undertaking functions as an 'open norm', which means that the concrete implementation of a focus on stakeholder interests and the longterm interest of the corporation as a whole remains very much dependent on the concrete direction chosen by the board. Moreover, it is well accepted that the actual characteristics of the corporation and its affiliated undertaking and the identification of the stakeholder interests affected by the corporation and its undertaking will affect the focus on specific interests and will affect the discretionary space for the board of directors to focus on specific stakeholder interests.

We conclude by arguing that the institutional model offers a number of highly interesting ways forward but that the open norm status of the institutional model means that both the internal consistency of constructs in Dutch company law and adjoining institutions need to be developed in order to further strengthen the focus on stakeholder rights and long-term value creation. In our view, a solution for the lack of direction for directors to discharge their duties can be found in formulating a purpose or, more particularly, in specifying the enduring success of the undertaking.

73. See, for example, the conclusion reached by Edward Rock regarding his position and the position Martin Lipton is taking in the debate on corporate purpose, stating that '[a]s discussed above, although I view the directors' duties in the context of a corporate auction to be a revealing example in which courts have to confront the core question of "for whom is the corporation managed" and not the exceptional case, we agree that Revlon is clear. We also agree that, in the day to day management of the firm, the board is not under any obligation to maximize share price. Moreover, we agree that shareholders' power to elect directors means that directors will be accountable to shareholders. Finally, we agree that "directors, once impaneled as corporate stewards, [can] manage with the interests of society and people in view" when they believe that doing so is rationally related to shareholder value, as it generally will be.' [emphasis added]. Rock, above n. 72, at 15. 